AGRITECH, Vol. 36, No. 4, November 2016, Hal. 424-432 DOI: http://dx.doi.org/10.22146/agritech.16766 ISSN 0216-0455 (Print), ISSN 2527-3825 (Online) Tersedia online di https://jurnal.ugm.ac.id/agritech/

\title{
Karakteristik Minuman Laktat Sari Buah Durian Lay (Durio kutejensis) yang Disuplementasi dengan Kultur Lactobacillus selama Penyimpanan pada Suhu Rendah
}

\author{
Characteristic of Durian Lay (Durio kutejensis) Lactic Beverage Supplemented with Lactobacillus \\ Culture during Cold Storage
}

\author{
Neti Yuliana, Tintan Noviyeziana, S. Sutikno \\ Program Studi Magister Teknologi Industri Pertanian, Universitas Lampung, Universitas Lampung, \\ Jl Sumantri Brojonegoro No. 1 Bandar Lampung, Indonesia \\ Email: neti.yuliana@fp.unilla.ac.id
}

Subismi: 24 Juli 2015; Penerimaan: 20 Januari 2016

\begin{abstract}
ABSTRAK
Tujuan penelitian ini adalah mengkaji karakteristik minuman laktat sari durian lay yang disuplementasi dengan kultur bakteri asam laktat (BAL) selama penyimpanan pada suhu rendah. Kultur BAL terdiri dari Lactobacillus plantarum FNCC-0265, Lactobacillus acidophillus FNCC-0051, dan campuran keduanya. Sari buah durian lay diinokulasi dengan kultur berumur 24 jam lalu diinkubasi pada suhu $37^{\circ} \mathrm{C}$ selama 2 jam dan kemudian disimpan selama $0,1,2,3$, dan 4 minggu. Perubahan $\mathrm{pH}$, total asam, gula, total sel BAL. Total padatan terlarut, viabilitas BAL, dan sensori selama penyimpanan dingin diukur. Hasil penelitian menunjukkan bahwa terjadi perubahan $\mathrm{pH}$ dari 4,79 ke 4,20; kandungan gula dari 4,52 ke $0,75 \%$; total padatan terlarut dari $8,93 \mathrm{ke} 7.97^{\circ} \mathrm{Bx}$, viabilitas BAL dari $100 \%$ menjadi $95,90 \%$, dan skor sensori dari 3,71 suka ke 3,40 (agak suka); sementara pada total asam terjadi peningkatan dari 0,33 ke 0,69\%; dan sel hidup BAL meningkat dari 8,86 menjadi 9,14 log CFU/mL. Berdasarkan parameter sensori, perlakuan kultur campuran Lactobacillus plantarum FNCC-0265 dan Lactobacillus acidophillus FNCC-0051 yang disimpan selama 2 minggu merupakan perlakuan terbaik. Sari buah durian lay ini mempunyai karakteristik sebagai berikut: $\mathrm{pH} 4,45$, total asam laktat $0,83 \%$, gula 2,20\%, sel hidup BAL 9,33 log CFU/mL, total padatan terlarut $9,16{ }^{\circ} \mathrm{Bx}$, dan karbohidrat $35,04 \%$. Asam organik yang terkandung pada jus durian lay ini adalah asam oksalat $(108 \mathrm{mg} / \mathrm{L})$, malat $(528 \mathrm{mg} / \mathrm{L})$, laktat (4382 mg/L) dan sitrat (351 mg/L).
\end{abstract}

Kata kunci: Sari buah durian lay fermentasi; bakteri asam laktat; minuman laktat

\begin{abstract}
The objective of this study was to characterize the durian lay juices supplemented by Lactic Acid Bacteria (LAB) culture during cold storage. The LAB cultures consisted of Lactobacillus plantarum FNCC-0265, Lactobacillus acidophillus FNCC-0051 and combination of these LABs. After being inoculated with a $24 \mathrm{~h}-$ old culture starters, durian lay juice was incubated at $37^{\circ} \mathrm{C}$ for 2 hours and kept at $4{ }^{\circ} \mathrm{C}$ for $0,1,2,3$ and 4 weeks. Changes in pH, total lactic acid, and sugar content, viable cell counts of LAB, total soluble solid, viability of LAB, and sensory characteristic during fermentation were measured. The results revealed that $\mathrm{pH}$ decreased from 4.79 to 4.20 ; sugar content reduced from 4.52 to $0.75 \%$; total soluble solid reduced from 8.93 to $7.97^{\circ} \mathrm{Bx}$, and sensory score reduced from 3.71 (like) to 3.40 (moderate like); while the total lactic acid increased from 0.33 to $0.69 \%$; viable cell counts of LAB increased from 8.86 to $9.14 \log \mathrm{CFU} / \mathrm{ml}$; and \% viability of LAB decreased from 100 to 95.90 , during storage. Combination of Lactobacillus plantarum FNCC-0265 and Lactobacillus acidophillus FNCC-0051 cultures at two weeks cold storage
\end{abstract}


period was the best treatment, based on the sensory and viable cell counts of LAB. The characteristics of this durian lay juice probiotic were $\mathrm{pH} 4.46$, total lactic acid $0.59 \%$, sugar content $2.13 \%$, viable cell counts of LAB 9.33 log CFU/ $\mathrm{mL}$, total soluble solid $9.60{ }^{\circ} \mathrm{Bx}$, and carbohydrate 45,05\%. This durian lay juice contained oxalate (107.56 mg/L), malic (527.895 mg/L), lactic (4381.49 mg/L) and citric (351.245 mg/L) acid.

Keywords: Durian lay; lactic acid bacteria; lactic beverage

\section{PENDAHULUAN}

Minuman laktat adalah minuman yang mengandung bakteri hidup asam laktat yang bermanfaat bagi kesehatan. Prado dkk. (2008) dan Soccol dkk. (2010) menyatakan bakteri yang menguntungkan kesehatan manusia dengan cara memperbaiki keseimbangan mikroflora intestinal disebut probiotik. Secara teknis FAO/WHO (2001), Guarner dan Schaafsma (1998), mendefinisikan probiotik adalah mikroba hidup yang jika dikonsumsi dalam jumlah tertentu menghasilkan efek kesehatan melebihi nutrisi. Dalam hal ini mikroba yang harus hidup sebelum dikonsumsi disarankan dalam jumlah besar, umumnya lebih dari $10^{9}$ sel (Prado dkk., 2008), agar menjaga jumlah yang cukup untuk bertahan hidup di usus besar, serta mendapatkan manfaat yang diinginkan.

Minuman laktat yang telah berkembang umumnya berbahan baku susu dan saat ini mulai pula dikembangkan yang berbahan baku nabati. Contoh minuman laktat berbahan baku nabati yang diteliti adalah minuman probiotik berbahan kacang-kacangan (Widowati dan Misgiyarta, 2005), buahbuahan seperti murbei (Zubaidah dkk., 2008), papaya-nanas (Hartati dkk., 2003), jeruk-apel (Marhamatizadeh dkk., 2012), noni (Wang dkk., 2009) dan berbahan baku sayuran seperti tomat (Yoon dkk., 2004), kubis (Etiyati, 2010), jagung (Nosrati dkk., 2014) dan wortel (Kun dkk., 2008; Manea dkk., 2013). Buah lainnya yang berpotensi dijadikan minuman laktat adalah buah durian lay. Durian lay (Durio kutejensis) tergolong buah berukuran besar dan merupakan kerabat dekat durian yaitu masuk dalam genus Durio. Lai atau Lay (Krismawati dan Sarwani, 2005). Sejauh ini, laporan penelitian minuman laktat dari durian lay belum ditemukan.

Durian lay beraroma lembut, warna daging atraktif (kuning tua atau oranye), dan panen pada musim yang berbeda dengan durian umumnya (Santoso, 2010). Warna kuning durian lay selain mencolok dan menarik, juga menunjukkan kandungan karoten atau provitamin A yang tinggi (Antarlina dkk., 2009; Djufry dan Jumberi, 2005). Vitamin A yang terkandung di dalamnya sebesar 3.420 SI, sedangkan buah durian lain hanya 603 SI (Wahdah dkk., 2003). Oleh karena itu, durian lay memiliki potensi untuk dikembangkan sebagai bahan baku industri makanan dan minuman, salah satunya yaitu dengan dikembangkan menjadi minuman laktat sari buah durian lay.
Sebagian besar produk komersial minuman probiotik menggunakan mikroba dari genus Lactobacillus dan Bifidobacterium. Setiap jenis mikroba dengan lama penyimpanan yang sesuai akan menghasilkan flavour yang berbeda pada minuman probiotik sari buah. Sejumlah penelitian menunjukkan bahwa produksi sejumlah asam laktat selama fermentasi sangat ditentukan oleh karakteristik kultur starternya. Selain jenis BAL, kultur tunggal atau campuran, serta lama penyimpanan dingin berpengaruh terhadap karakteristik minuman probiotik yoghurt sari jagung (Etiyati, 2010); sari ubi jalar (Yuliana, 2010), minuman sari kurma (Retnowati dan Kusnadi, 2014); minuman sari tomat (Yoon dkk., 2004). Kultur campuran mempunyai sejumlah kelebihan dibandingkan penggunaan kultur tunggal, misalnya senyawa-senyawa yang dihasilkan bersifat saling berkomplemen. Akan tetapi, biokima fermentasi kultur campuran lebih sulit dipelajari karena melibatkan lebih dari satu mikroorganisme (Bostid, 1992).

Bakteri asam laktat genus Lactobacillus merupakan kultur yang biasa digunakan dalam riset fermentasi minuman probiotik (Retnowati dan Kusnadi, 2014; Usmiati dan Utami, 2008; Khoiriyah dan Fatchiyah, 2013; Winarti dkk., 2013) dan juga merupakan mikroba yang digunakan sebagian besar produk komersial minuman probiotik. Pada penelitian ini dipilih penambahan jenis BAL genus Lactobacillus (L. plantarum dan L. acidophillus) dalam bentuk kultur tunggal dan campuran, dan dievaluasi pengaruhnya terhadap karakterisitik minuman laktat sari buah durian lay selama penyimpanan dingin. Penelitian juga mengevaluasi perlakuan penyimpanan dingin yang masih dapat mempertahankan karakterisitik sensory dan jumlah sel hidup bakteri asam lakat minuman sari buah

\section{METODE PENELITIAN}

\section{Bahan}

Bahan utama yang digunakan dalam pembuatan minuman probiotik sari buah ini adalah buah durian lay (Durio kutejensis) yang berasal dari Balikpapan, Kalimantan Timur. Starter Lactobacillus plantarum FNCC-0265 dan Lactobacillus acidhopillus FNCC 0051 dalam bentuk kultur murni diperoleh dari Pusat Antar Universitas Pangan dan Gizi, UGM Yogyakarta. 


\section{Metode}

Rancangan percobaan yang digunakan dalam penelitian ini adalah Rancangan Acak Kelompok Lengkap (RAKL) factorial dengan dua faktor dan tiga ulangan. Faktor pertama adalah jenis BAL (L) yang terdiri dari 3 taraf, yaitu $L$. plantarum (L1), L. acidophilus (L2), dan campuran L. plantarum $+L$. acidophilus (L3) dengan proporsi 1:1, sedangkan faktor kedua adalah lama penyimpanan dingin pada suhu $5{ }^{\circ} \mathrm{C}(\mathrm{T})$, yang terdiri dari 5 taraf yaitu 0 (T0), 1 (T1), 2 (T2), 3 (T3), dan 4 minggu (T4). Pengamatan dilakukan terhadap total $\mathrm{BAL}, \mathrm{pH}$, total asam laktat, total padatan terlarut, viabilitas, dan kadar gula pereduksi. Data tersebut kemudian dianalisis dengan sidik ragam untuk mendapatkan penduga ragam galat dan uji signifikan untuk mengetahui ada tidaknya perbedaan antar perlakuan. Analisis lebih lanjut dilakukan dengan uji polinomial ortogonal pada taraf nyata 5 atau $1 \%$, sedangkan data uji organoleptik diolah lebih lanjut dengan uji Duncan. Hasil perlakuan terbaik kemudian dilanjutkan untuk dikarakterisasi mutunya (warna, rasa dan aroma, total asam laktat, viabilitas BAL, total padatan terlarut, gula pereduksi, analisa proksimat, dan asam organik).

\section{Pelaksanaan Penelitian}

\section{Persiapan starter}

Kultur murni Lactobacillus plantarum FNCC-0265 dan Lactobacillus acidophilus FNCC 0051 seluruhnya dipindahkan ke dalam tabung reaksi berisi $10 \mathrm{~mL}$ media MRS Broth (Sigma-Aldrich, USA). Selanjutnya dibuat kultur induk dengan cara sebanyak $1 \mathrm{~mL}$ MRS Broth tersebut diinokulasikan ke dalam $5 \%$ media susu skim yang disterilisasi pada suhu $121{ }^{\circ} \mathrm{C}$ selama 15 menit (Autoclave Wide Calf, Daihan Scientific), kemudian diinkubasi selama 2 hari pada suhu $37^{\circ} \mathrm{C}$ (Incubator Memmert IF30, Germany). Selanjutnya dari kultur induk diinokulasi ke dalam media yang sama yaitu sebanyak $4 \%(\mathrm{v} / \mathrm{v})$ dan diinkubasi selama 48 jam pada suhu $37{ }^{\circ} \mathrm{C}$ sehingga diperoleh kultur antara. Selanjutnya dari kultur antara diinokulasikan $4 \%$ (v/v) ke dalam media yang terdiri dari $5 \%(\mathrm{~b} / \mathrm{v})$ susu skim dan $3 \%$ $(\mathrm{b} / \mathrm{v})$ glukosa $(\mathrm{D}(+)$ glucose Sigma Chem, USA) yang telah disterilisasi terlebih dahulu, kemudian diinkubasi selama 24 jam pada suhu $37^{\circ} \mathrm{C}$, sehingga mencapai lebih kurang $10^{10}$ $\mathrm{CFU} / \mathrm{mL}$ dan siap digunakan sebagai kultur kerja.

\section{Pembuatan Sari Buah Durian Lay}

Buah durian lay dikupas lalu daging buah dipisahkan dari bijinya. Daging buah kemudian dihancurkan dengan blender (Blender Sharp Indonesia EM11R) dan ditambahkan air dengan perbandingan 1:5 (b:v). Selanjutnya campuran ini disaring dengan kain saring (Hero) sehingga diperoleh sari buah durian lay. Sari buah durian lay kemudian ditambahkan $5 \%(b / v)$ sukrosa sehingga diperoleh sari buah dengan total padatan terlarut sekitar $10{ }^{\circ} \mathrm{Bx}$. Sari buah selanjutnya dipasteurisasi pada suhu $75{ }^{\circ} \mathrm{C}$ selama 15 menit dan didinginkan.

\section{Fermentasi Minuman Probiotik Sari Buah Durian Lay}

Sari buah durian lay yang telah dipasteurisasi selanjutnya disuplementasi dengan kultur kerja L. plantarum, L. acidophilus dan campuran keduanya dengan proporsi 1:1 masing-masing sebanyak $4 \%$ dengan kerapatan sel ratarata $10^{10} \log \mathrm{CFU} / \mathrm{mL}$, sehingga jumlah BAL yang berada di dalam media sari buah durian mendekati $10^{8} \mathrm{CFU} / \mathrm{mL}$. Sari buah durian lay kemudian diinkubasi pada suhu $37^{\circ} \mathrm{C}$ selama 2 jam lalu dilakukan penyimpanan dingin pada suhu $4{ }^{\circ} \mathrm{C}$ $(0,1,2,3$ dan 4 minggu). Pengamatan dilakukan terhadap $\mathrm{pH}$ (AOAC, 2000), total BAL dengan metode hitung cawan (Harrigan, 1998), total asam laktat dengan metode titrasi (AOAC, 2000), total padatan terlarut dengan refraktometer (Atago hand refractometer-Japan), gula reduksi dengan metode Luff Schoorl (AOAC, 2000), viabilitas BAL (Shin dkk, 2000) dan uji hedonik (kesukaan) terhadap penerimaan keseluruhan (Lawless, 2013).

\section{Karakterisasi Minuman Probiotik PerlakuanTerbaik}

Pelaksanaan tahapan ini mengkuti prosedur pelaksanaan penelitian tahapan sebelumnya. Kultur yang ditambahkan adalah kultur terbaik yaitu kultur campuran dan lama penyimpanan 2 minggu. Pengamatan dilakukan terhadap warna, rasa dan aroma, total asam laktat, viabilitas BAL, total padatan terlarut, gula reduksi, yang prosedurnya mengikuti prosedur penelitian tahap sebelumnya, analisa proksimat yang meliputi kadar lemak, kadar air, kadar protein, kadar abu (AOAC, 2000), serta kandungan asam organik menggunakan high performance liquid chromatography (HPLC) Hitachi 4200 UV/VIS dengan kolom C-18 (octadecyl silica 224; 220 $\times 4.6 \mathrm{~mm}$ ) (Lab Pengujian Balai Besar Pascapanen-Bogor). Data-data tersebut kemudian disajikan secara deskriptif.

\section{HASIL DAN PEMBAHASAN}

\section{Karakteristik Kimia dan Mikrobiologis}

Hasil pengamatan terhadap karakteristik kimia dan mikrobiologi minuman probiotik sari buah durian lay dapat dilihat pada Tabel 1. Total BAL, total asam, $\mathrm{pH}$, dan viabilitas minuman probiotik sari buah durian lay, tidak dipengaruhi oleh jenis kultur BAL namun dipengaruhi oleh lama penyimpanan. Perlakuan kultur tunggal dan kultur campuran (kombinasi keduanya) hanya memberikan perbedaan nilai gula reduksi dan total padatan terlarut. Perlakuan lama 
penyimpanan dingin memberikan pengaruh sangat nyata terhadap seluruh karakteristik yang diamati dengan pola linier ataupun kuadratik. Perubahan total BAL, pH, total asam dan viabilitas probiotik minuman probiotik sari buah durian lay karena perbedaan lama penyimpanan dingin tidak bergantung pada jenis kultur bakteri asam laktat (tidak terjadi interaksi antara perlakuan jenis kultur dan lama penyimpanan dingin).

Selama penyimpanan dingin, total BAL meningkat sampai penyimpanan minggu ke 2, kemudian menurun kembali setelahnya dengan jumlah yang tidak berbeda antara perlakuan starter tunggal dan starter campuran. Selama penyimpanan dingin BAL masih dapat tumbuh sehingga jumlah sel meningkat hingga minggu ke 2 (9,27-9,33 log $\mathrm{CFU} / \mathrm{mL}$ ), dan ketahanan sel BAL mulai menurun pada minggu ke 3 sampai dengan minggu ke 4 (9,07-9,14 log $\mathrm{CFU} / \mathrm{mL}$ ). Pada minggu kedua nutrisi yang terdapat pada minuman probiotik sari buah durian lay tersebut masih dapat memenuhi kebutuhan nutrisi BAL. Penurunan jumlah sel pada penyimpanan minggu selanjutnya menunjukkan BAL tidak dapat lagi memanfaatkan nutrisi pada minuman tersebut untuk pertumbuhan dan metabolismenya dan atau terdapat gangguan terhadap metabolismenya. Gangguan metabolisme pertumbuhan mikroba dapat terjadi antara lain karena berkurangnya nutrisi, terdapatnya inhibisi substrat, inhibisi produk atau metabolit. Saarela dkk (2009) memfokuskan pada tingkat keasaman dan suhu yang menjadi faktor pembatas ketahanan probiotik. Selain $\mathrm{pH}$ dan suhu, Guemonde dan Sanchez (2012) menyebutkan bahwa stabilitas probiotik selama penyimpanan juga dipengaruhi oleh aw, oksigen dan kehadiran senyawa kimia serta adanya mikroba lain. Percobaan Espinoza dan Navarro (2010) menunjukkan bahwa penurunan $\mathrm{pH}$, akumulasi asam laktat, diasetil, dan

Tabel 1. Karakteristik kimia dan mikrobiologis minuman probiotik sari buah durian lay

\begin{tabular}{|c|c|c|c|c|c|c|}
\hline Kode Sampel & $\begin{array}{l}\text { Total BAL }(\log \\
\text { CFU } / \mathrm{ml})\end{array}$ & $\begin{array}{l}\text { Total asam } \\
(\%)\end{array}$ & $\mathrm{pH}$ & $\%$ Viabilitas & $\begin{array}{c}\text { Gula pereduksi } \\
(\%)\end{array}$ & $\begin{array}{c}\text { Padatan terlarut } \\
\left({ }^{\circ} \mathrm{Bx}\right)\end{array}$ \\
\hline L1T0 & 8,86 & 0,33 & 4,79 & 100,00 & 4,53 & 9,16 \\
\hline L1T1 & 9,29 & 0,45 & 4,72 & 95,41 & 4,65 & 8,92 \\
\hline L1T2 & 9,31 & 0,63 & 4,61 & 95,22 & 3,18 & 9,09 \\
\hline L1T3 & 9,17 & 0,69 & 4,36 & 96,67 & 2,29 & 8,93 \\
\hline L1T4 & 9,07 & 0,76 & 4,38 & 97,66 & 2,45 & 8,66 \\
\hline L2T0 & 8,81 & 0,33 & 4,68 & 100,00 & 4,32 & 8,51 \\
\hline L2T1 & 9,29 & 0,51 & 4,50 & 94,72 & 4,37 & 8,69 \\
\hline $\mathrm{L} 2 \mathrm{~T} 2$ & 9,27 & 0,60 & 4,50 & 94,99 & 2,50 & 9,10 \\
\hline L2T3 & 9,21 & 0,72 & 4,48 & 95,55 & 1,93 & 8,13 \\
\hline L2T4 & 9,13 & 0,79 & 4,26 & 96,40 & 1,37 & 8,43 \\
\hline L3T0 & 8,95 & 0,32 & 4,66 & 100,00 & 4,32 & 9,02 \\
\hline L3T1 & 9,33 & 0,49 & 4,56 & 95,12 & 4,25 & 8,66 \\
\hline L3T2 & $9,33 *$ & 0,63 & 4,50 & 95,90 & 2,19 & 8,99 \\
\hline L3T3 & 9,26 & 0,66 & 4,44 & 96,60 & 1,01 & 8,94 \\
\hline L3T4 & 9,14 & 0,79 & 4,20 & 97,90 & 0,75 & 7,97 \\
\hline Interaksi L \& T & tn & tn & tn & tn & $*$ & $*$ \\
\hline L1,L2 vs L3 & tn & Th & tn & tn & $* *$ & $* *$ \\
\hline L1 vs L2 & tn & $\mathrm{Th}$ & tn & tn & $* *$ & tn \\
\hline Liner $\mathrm{T}$ & $* *$ & $* *$ & $* *$ & tn & $* *$ & $*$ \\
\hline Kuadratik T & $* *$ & $* *$ & $* *$ & $* *$ & $* *$ & $* *$ \\
\hline
\end{tabular}

Keterangan :

$\mathrm{L}_{1}$ : L. plantarum, $\mathrm{L}_{2}:$ L. acidophilus, $\mathrm{L}_{3}$ : Kombinasi $\mathrm{L}_{1}$ dan $\mathrm{L}_{2}$

tn : tidak berbeda nyata,

* : berbeda nyata pada tingkat kepercayaan $95 \%$,

** : berbeda nyata pada tingkat kepercayaan $99 \%$,

$\mathrm{T}$ : Perlakuan Penyimpanan dingin, $\mathrm{T}_{0}$ : Penyimpanan dingin minggu ke-0

$\mathrm{T}_{1^{-}}$: Penyimpanan dingin masing-masing minggu ke-1, 2,3 , dan 4 
asetaldehid hasil pertumbuhan dan fermentasi merupakan faktor penyebab kehilangan viabilitas probiotik dalam susu. Pada penelitian minuman durian lay ini, $\mathrm{pH}$ media sudah turun menjadi 4,50-4,60 dan akumulasi asam laktat telah mencapai 0,60-0,63\%.

Total BAL minuman probiotik sari buah durian lay yang disimpan pada suhu $4{ }^{\circ} \mathrm{C}$ selama $0-4$ minggu berkisar antara 8,86- 9,33 $\log \mathrm{CFU} / \mathrm{mL}$. Hal ini berarti, total BAL minuman probiotik sari buah durian lay semua perlakuan lebih besar dari 8,86 $\log \mathrm{CFU} / \mathrm{mL}\left(7,24 \times 10^{8} \log / \mathrm{mL}\right)$ dan memenuhi syarat total BAL untuk minuman probiotik yaitu minimal $10^{7}$ CFU/mL (SNI 2009). Menurut Prado dkk. (2008), minimal sel di dalam produk minuman probiotik sebaiknya $10^{9} \mathrm{CFU} /$ $\mathrm{mL}$.

Selama penyimpanan dingin terjadi peningkatan total asam laktat secara kuadratik. Total asam laktat minuman probiotik sari buah durian lay tertinggi dihasilkan dari perlakuan penyimpanan dingin minggu ke-2, yaitu 0,63-0,83 $\%$. Hal ini sejalan dengan data total BAL yang juga tertinggi pada penyimpanan dingin minggu kedua. Asam laktat merupakan produk utama metabolisme bakteri asam laktat yang dalam jalur metabolismenya melibatkan enzim-enzim tertentu (Wright dan Axelsson, 2011). Metabolit primer akan meningkat jika pertumbuhan bakteri asam laktat dan sintesa enzim telah tercukupi. Hasil penelitian sejenis menunjukkan semakin baik pertumbuhan BAL, semakin tinggi asam laktat yang dihasilkan sampai waktu tertentu oleh BAL (Widowati dan Misgiyarta, 2005; Marhamatizadeh dkk., 2012; Wang dkk., 2009; Yoon dkk., 2006). Pada penelitian ini total asam seluruh perlakuan penyimpanan dingin untuk semua jenis BAL (berkisar antara 0,33 - 0,79\%) memenuhi persyaratan total asam SNI. Total asam yang harus dimiliki oleh minuman probiotik menurut SNI- Badan Standarisasi Nasional 2009 adalah $0,2-0,9 \%$. Total asam yang dilaporkan beberapa peneliti adalah $0,11-0,97 \%$ pada minuman probiotik jus kubis (Yoon dkk., 2006) dan 0,20 - 0,93\% pada minuman probiotik jus noni (Wang dkk., 2009).

Sejalan dengan peningkatan total asam, $\mathrm{pH}$ minuman probiotik sari buah durian lay disimpan pada penyimpanan dingin suhu $4{ }^{\circ} \mathrm{C}$ selama 0-4 minggu turun dari 4,79 menjadi 4,20 mengikuti pola kuadratik. Nilai $\mathrm{pH}$ perlakuan minuman probiotik sari buah durian lay yang memenuhi syarat keamanan minuman dari patogen $(\mathrm{pH} \mathrm{4,60)}$ adalah pada penyimpanan minggu kedua-empat untuk semua jenis starter BAL. Selama fermentasi, substrat gula dikonversi menjadi asam laktat dan terakumulasi sehingga $\mathrm{pH}$ minuman semakin asam. Fermentasi yang melibatkan bakteri asam laktat menghasilkan peningkatan total asam tertitrasi (asam laktat) yang kemudian menyebabkan penurunan $\mathrm{pH}$ jus buah (Marhamatizadeh dkk., 2012; Yoon dkk., 2004; Yoon dkk.,
2006; Nosrati dkk., 2014). Selain asam laktat, metabolisme lebih lanjut karbohidrat sederhana oleh BAL dapat dihasilkan asam asetat, asam malat, asam suksinat dan senyawa volatil lainnya seperti etil alkohol, dan asetal dehid tergantung pada kondisi dan jenis BAL (Wright dan Axelsson, 2012). Misalnya, jenis BAL: heterofermentatif akan memproduksi $\mathrm{CO}_{2}$, ethanol, dan asetat selain asam laktat. Sebagai respon terhadap substrat terbatas pada kondisi anaerobik, BAL juga dapat melakukan jalur metabolisme pyruvat menjadi asam format dan asetil CoA yang akhirnya dapat dikonversi menjadi alkohol. Pada BAL genera Lactococcus dan Leuconostoc, jalur metabolisme menghasilkan diasetyl dan acetoin (Wright dan Axelsson, 2012).

Viabilitas BAL minuman probiotik sari buah durian lay disimpan pada penyimpanan dingin suhu $4{ }^{\circ} \mathrm{C}$ selama $0-4$ minggu menurun dari $100 \%$ menjadi 94,72\%, mengikuti pola kuadratik dengan besaran yang tidak berbeda antara jenis kultur BAL. Penurunan viabilitas dapat disebabkan oleh terakumulasinya sisa metabolisme yang mempunyai efek kurang menguntungkan bagi kultur L. plantarum, L.acidhopilus maupun kultur campuran. Menurut Nurwantoro dkk. (2009); Hadadji dan Bensoltane (2006), Espinoza dan Navarro (2010), penurunan viabilitas dapat terjadi karena adanya efek antimikrobia dari diasetil, asam asetat dan asam laktat yang terakumulasi di dalam produk, dan terkadang disebabkan adanya bakteriosin (Lahtinen dkk., 2011). Pada penelitian ini, walaupun terjadi penurunan viabilitas tetapi sampai minggu keempat penyimpanan jumlah sel probiotik masih tinggi yaitu 94,72 \% (9,29 log CFU/ $\mathrm{mL}$ ). Hal ini menunjukkan bahwa semua jenis BAL pada penyimpanan suhu dingin tersebut masih dapat tumbuh dan bertahan dengan baik sampai 4 minggu. Lama penyimpanan masih dapat diperpanjang jika dibandingkan dengan yang dilaporkan oleh Yoon dkk. (2006) yang mengevaluasi $L$. plantarum dan L. delbrueckii pada minuman jus bit merah yang dapat bertahan sampai 6-8 $\log$ CFU/mL selama 28 hari pada suhu $4{ }^{\circ} \mathrm{C}$. Nurwantoro dkk. (2009) melaporkan bahwa kemampuan hidup BAL pada minuman dingin kemungkinan disebabkan oleh tingginya populasi BAL pada kultur awal yang digunakan dan tingginya bahan padat pada minuman tersebut sehingga memberikan perlindungan terhadap BAL selama penyimpanan dingin. Total padatan terlarut pada minuman durian lay berkisar antara $7-9{ }^{\circ} \mathrm{Bx}$ dan total karbohidrat mencapai $50 \%$, sementara kultur yang ditambahkan mencapai $10^{10} \mathrm{sel} / \mathrm{mL}$.

Gula reduksi minuman probiotik sari buah durian lay yang disimpan dingin selama 4 minggu mengalami penurunan dari 4,65 menjadi 0,75\%. Penurunan gula reduksi terjadi secara linear dan berbeda besarannya antara perlakuan starter tunggal dan campuran. Pada akhir penyimpanan, 
kadar rata-rata gula reduksi yang paling rendah ditunjukkan pada perlakuan kombinasi L. plantarum dan L. acidophilus, yaitu sebesar $0,75 \%$ dibandingkan dengan kultur tunggal $L$. plantarum (2,45\%) dan L. acidophilus (1,37\%). Penurunan gula reduksi terjadi karena konsumsi gula oleh BAL sebagai susbtrat pertumbuhannya dan konsumsi gula oleh campuran dua jenis BAL tersebut lebih tinggi dibandingkan dengan kultur tunggal (L. plantarum atau L. acidophilus saja).

Total padatan terlarut minuman probiotik sari buah durian lay disimpan dingin suhu $4{ }^{\circ} \mathrm{C}$ selama 4 minggu terjadi peningkatan dari 7,87-9,16 ${ }^{\circ} \mathrm{Bx}$ yang besarannya berbeda antara kultur tunggal dan campuran. Peningkatan total padatan terlarut tersebut mengikuti pola kuadratik yaitu meningkat sampai minggu kedua dan turun setelahnya. Total padatan terlarut tertinggi terdapat pada perlakuan kombinasi BAL pada penyimpanan dingin minggu ke-2, yaitu sebesar 9,16\%, akan tetapi, pada akhir penyimpanan, total padatan terlarut perlakuan suplementasi kultur tunggal lebih tinggi dibandingkan pada kultur campuran $L$. plantarum dan $L$. acidophilus. Metabolit asam laktat dan asam organik lainnya yang diproduksi selama fermentasi akan terakumulasi dalam cairan fermentasi. Asam-asam organik ini bersama sama dengan total gula terlarut, dan sel-sel mikroba akan terhitung sebagai total padatan terlarut. Selama pendinginan terjadi peningkatan total asam, total BAL sampai minggu kedua, sehingga total padatan terlarut tertinggi juga terjadi pada minggu kedua. Namun karena konsumsi gula reduksi ketiga starter berbeda maka pada akhir penyimpanan terjadi perbedaan total padatan terlarut antara starter tunggal dan campuran. Total padatan terlarut minuman probiotik menurut SNI 202981 (2009) minimal 8,2 \%. Jadi, semua perlakuan memenuhi persyaratan SNI, kecuali perlakuan jenis BAL L. acidophillus yang disimpan 3 minggu dan perlakuan kombinasi jenis BAL yang disimpan 4 minggu (Tabel 1).

\section{Karakteristik Sensorial}

Penerimaan keseluruhan (warna, rasa, aroma, dan penampakan) minuman probiotik sari buah durian lay yang disimpan pada penyimpanan dingin suhu $4{ }^{\circ} \mathrm{C}$ selama $0-4$ minggu disajikan pada Tabel 2. Perlakuan jenis BAL dan lama penyimpanan dingin serta interaksi keduannya berpengaruh nyata terhadap penerimaan keseluruhan minuman sari buah lay. Skor penerimaan keseluruhan minuman probiotik sari buah durian lay berkisar antara 3,09 (agak suka) hingga 3,74 (mendekati suka).

Skor penerimaan keseluruhan minuman probiotik sari buah durian lay tertinggi terdapat pada perlakuan jenis BAL campuran L. plantarum dan L. acidophillus yang disimpan dingin selama 2 minggu. Hal ini mengindikasikan bahwa penggunaan kultur campuran L. plantarum dan L. achidophilus dapat memperbaiki sifat sensori minuman probiotik sari
Tabel 2. Karakteristik sensori penerimaan keseluruhan

\begin{tabular}{cc}
\hline Kode sampel & Skor penerimaan keseluruhan \\
\hline L1T0 & $\mathbf{3 , 7 1 ^ { \text { cde } }}$ \\
L1T1 & $3,52^{\mathrm{abcde}}$ \\
L1T2 & $3,19^{\mathrm{ab}}$ \\
L1T3 & $3,32^{\mathrm{abc}}$ \\
L1T4 & $3,10^{\mathrm{a}}$ \\
L2T0 & $\mathbf{3 , 7 5 ^ { \mathrm { cde } }}$ \\
L2T1 & $3,38^{\mathrm{abcd}}$ \\
L2T2 & $3,13^{\mathrm{a}}$ \\
L2T3 & $3,38^{\mathrm{abcd}}$ \\
L2T4 & $3,32^{\mathrm{abc}}$ \\
L3T0 & $\mathbf{3 , 8 4 ^ { \mathrm { de } }}$ \\
L3T1 & $3,65^{\mathrm{bcd}}$ \\
L3T2 & $\mathbf{4 , 1 9}$ \\
L3T3 & $3,49^{\mathrm{abcd}}$ \\
L3T4 & $3,43^{\mathrm{abcd}}$ \\
\hline
\end{tabular}

Keterangan:

Angka yang diikuti huruf yang sama menunjukkan hasil yang tidak berbeda nyata dengan uji Duncan pada tingkat kepercayaan $95 \%$

$\mathrm{L}_{1}$ : L.plantarum, $\mathrm{L}_{2}:$ L. acidophilus, $\mathrm{L}_{3}$; Kombinasi $\mathrm{L}_{1}$ dan $\mathrm{L}_{2}$

$\mathrm{T}_{0}$ : Penyimpanan dingin minggu ke- $0 ; \mathrm{T}_{1}$ : Penyimpanan dingin minggu ke-1

$\mathrm{T}_{2}$ : Penyimpanan dingin minggu ke-2; $\mathrm{T}_{3}$ : Penyimpanan dingin minggu ke$3 ; \mathrm{T}_{4}$ : Penyimpanan dingin minggu ke-4.

Skor penerimaan keseluruhan 1 = sangat tidak suka, skor $2=$ tidak suka, skor $3=$ agak suka, skor $4=$ suka, dan skor $5=$ sangat suka

buah durian lay. Penggunaan kedua kultur ini diduga menghasilkan perpaduan aroma yang baik pada minuman tersebut. BAL selama fermentasi selain mengkatabolisme gula menjadi asam laktat juga mempunyai kemampuan memetabolisme subtrat lainnya menjadi senyawa aromatik seperti diasetil, asetoin dan butanediol (Wright dan Axelsson, 2011). Penggunaan kultur campuran untuk meningkatkan skor sensory produk fermentasi telah banyak dilaporkan peneliti. Pada minuman probiotik yoghurt sari jagung dengan kombinasi S. thermophillus dan L. bulgaricus (Etiyati, 2010); minuman probiotik fermentasi sari buah kurma menggunakan kultur campuran (L. casei dan L. plantarum) (Retnowati dan Kusnadi, 2014); fermentasi pikel ubi jalar dengan kultur campuran L. plantarum dan Leuconostoc mesenteroides (Yuliana dkk., 2013).

\section{Karakteristik Minuman Probiotik Sari Buah Durian Lay}

Minuman probiotik sari buah durian lay pada perlakuan kombinasi L. plantarum dan L. acidophilus pada penyimpanan dingin minggu ke-2, mempunyai karakteristik warna kuning jingga, rasa agak asam, dan aroma agak 
terdeteksi aroma durian lay. Secara mikrobiologis perlakuan ini juga memenuhi persyaratan karakterisrtik minuman SNI 2981:2009, yaitu memiliki kandungan BAL $\geq 1 \times 10^{6} / \mathrm{mL}$. Karakteristik kimia dam mikrobiologis keseluruhan minuman probiotik dengan perlakuan kombinasi BAL dan disimpan selama 2 minggu dapat dilihat pada Tabel 3.

Tabel 3. Karakteristik kimia dan mikrobiologi minuman perlakuan terbaik

\begin{tabular}{lcc}
\hline Parameter & Kandungan & Satuan \\
\hline Total BAL & 9,41 & Log CFU/ml \\
Total asam & 0,59 & $\%$ \\
$\mathrm{pH}$ & 4,46 & - \\
Kadar gula reduksi & 2,13 & $\%$ \\
Total padatan terlarut & 9,60 & $\%$ \\
Air & 52,12 & $\%$ \\
Karbohidrat & 45,05 & $\%$ \\
Lemak & 0,41 & $\%$ \\
Protein & 1,05 & $\%$ \\
Abu & 0,46 & $\mathrm{mg} / \mathrm{L}$ \\
Asam laktat & 4381,49 & $\mathrm{mg} / \mathrm{L}$ \\
Asam oksalat & 107,56 & $\mathrm{mg} / \mathrm{L}$ \\
Asam malat & 527,89 & $\mathrm{mg} / \mathrm{L}$ \\
Asam sitrat & 351,25 &
\end{tabular}

Warna pada minuman probiotik sari buah durian lay berasal dari warna daging buah durian lay yang berwarna kuning - jingga. Warna jingga berkurang setelah dilakukan pengenceran 1:5 untuk memperoleh minuman jus probiotik dengan konsistensi yang diinginkan. Warna jingga mencerminkan kandungan beta-karoten yang merupakan provitamin A dan berkorelasi positif dengan kandungan vitamin A (Antarlina, 2009) yang lebih tinggi dari durian lainnya yaitu 3420 SI, sedangkan buah durian hanya 603 SI (Wahdah dkk., 2003). Rasa agak asam berasal dari senyawa asam organik hasil proses metabolisme BAL. Wright dan Axelsson (2011) menyatakan bahwa senyawa asam organik yang dapat dihasilkan fermentasi bakteri asam laktat antara lain asam laktat, asam malat, asam piruvat, dan asam asetat. Pada penelitian ini, asam organik yang terdeteksi adalah asam oksalat, asam malat, asam sitrat, dan asam laktat dengan kadar tertinggi yaitu $4382 \mathrm{mg} / \mathrm{L}$ (Tabel 3).

Aroma minuman probiotik sari buah durian lay ini masih terdekteksi aroma durian lay. Durian lay memiliki aroma yang khas yaitu sangat lembut bahkan hampir tidak beraroma menyengat atau kadang beraroma wangi mawar. Aroma yang lembut ini sesuai untuk konsumen yang menolak durian yang pada kesan pertama dengan baunya yang sangat menyengat (Djufry dan Jumberi, 2005). Komponen kimia aroma buah durian lay sejauh ini belum diketahui, namun demikian Yuliana (2013) menyatakan bahwa, aroma harum buah durian pada umumnya disebabkan oleh aroma senyawa ester.

\section{KESIMPULAN}

Karakterisitk minuman laktat sari buah durian lay yang disuplementasi L. plantarum FNCC-0265, Lactobacillus. FNCC-0051, dan campuran keduanya tidak menunjukkan perbedaan total $\mathrm{BAL}$, total asam, $\mathrm{pH}$, dan viabilitas, tetapi terdapat perbedaan karakterisitk sensory, gula pereduksi, dan total padatan terlarut. Lama penyimpanan suhu dingin menurunkan $\mathrm{pH}$, kandungan gula pereduksi, total padatan terlarut, viabilitas dan skor sensory. Penyimpanan dingin 4 ${ }^{\circ} \mathrm{C}$ sampai 4 minggu masih dapat mempertahankan viabilitas BAL minuman probiotik durian lay pada tingkat $10^{9} \mathrm{sel} / \mathrm{mL}$. Suplementasi campuran L. plantarum dan L. acidophilus dengan lama penyimpanan dingin $\left(4{ }^{\circ} \mathrm{C}\right) 2$ minggu, menghasilkan karakteristik sensori paling disukai. Minuman laktat ini mempunyai $\mathrm{pH} 4,45$, total asam laktat $0,83 \%$, gula pereduksi 2,20\%, sel hidup BAL 9,33 log CFU/mL, total padatan terlarut $9,16^{\circ} \mathrm{Bx}$, dan karbohidrat 35,04\%, serta campuran asam organik seperti oksalat, malat, laktat, dan sitrat.

\section{DAFTAR PUSTAKA}

AOAC. (2000). Official Methods of Analysis. The Associate of Analitical Chemist (AOAC) Inc. New York.

Antarlina, S.S. (2009). Identifikasi sifat fisik dan kimia buahbuahan lokal Kalimantan. Buletin Plasma Nutfah 15(2): 80-90.

Bostid (Board on Science and Technology for International Development). (1992). Applications of Biotechnology to Traditional Fermented Foods. The National Academies Press.

Djufry, F. dan Jumberi, A. (2005). Penggalian Data Pendukung Domestikasi dan Komersialisasi Jenis, Spesies dan Varietas Tanaman Buah di Kalimantan Selatan. Prosiding Lokakarya I : Domestikasi dan Komersialisasi Tanaman Hortikultura. Jakarta. 15 September 2005. Hlm 35-48.

Etiyati (2010). Pengaruh Penambahan Sukrosa dan Jenis Bakteri pada Pembuatan Yoghurt dari Jagung (Zea mays L.). Skripsi. Universitas Islam Negeri Sunan Kalijaga, Yogyakarta.

Espinoza, Y.R. dan Navarro, Y.G. (2010). Non dairy probiotic product. Food Microbiology 27(1): 1-10. 
FAO/WHO. (2001). Health, Nutritional Properties of Probiotics in Food Including Powder Milk with Live Lactic Acid Bacteria. Cordoba, Agrentina: Food and Agriculture Organization of the United Nations and WHO Expert Consultation Report.

Guemonde, M. dan Sanchez, B. (2012). Enhancing probiotic stability in industrial process. Microbial Ecology in Health and Disease 23: 18562.

Guarner, F. dan Schaafsma, G.J. (1998). Probiotics. Food Microbiology 39: 237-238.

Hadadji, M. dan Bensoltane, A. (2006). Gwroth and lactic acid production by Bifidobacterium bifidum in cheddar chesse. Journal of Dairy Science 77(10): 2854-2864.

Harrigan, W.F. (1998). Laboratory Methods in Food Microbiology. Academic Press.

Hartati, S., Harmayani, E., Rahayu, E.S. dan Utami, T. (2003). Viabilitas dan stabilitas Lactobacillus plantarum mut7 FNCC 250 yang disuplementasikan dalam sari buah pepaya-nanas selama penyimpanan. Jurnal Teknologi dan Industri Pangan 14(2): 182-187.

Khoiriyah, L.K. dan Fatchiyah (2013). Karakter biokimia dan profil protein yoghurt kambing PE difermntasi bakteri asam laktat. The Journal of Experimental Life Science 3(1): 1-6.

Krismawati, A. dan Sarwani, M. (2005). Penggalian data pendukung domestikasi dan komersialisasi jenis, spesies dan varietas tanaman buah di Kalimantan Tengah. Prosidong Lokakarya I: Domestikasi dan Komersialisai Tanaman Hortikultura. JAKARTA 15 september 2005. Hlm 49-54

Kun, S., Rezessy-Szabo, J.M., Nguyen, Q.D. dan Hoschke, A. (2008) Changes of microbial population and some components in carrot juice during fermentation with selected Bifidobacterium strains. Process Biochemistry 43: 816-821.

Lahtinen, S., Ouwehand, A.C., Salminen, S. dan Wright, A.V. (2011). Lactic Acid Bacteria Microbiological and Functional Aspects, Fouth Edition. CRC Press, New York.

Lawless, H.T. (2013). Laboratory Exercises for Sensory Evaluation. XIV, 1-151. Spinger.

Manea, J., Buruleanu, L.C. dan Ploscutanu, G. (2013). The evaluation of lactic fermentation yield of carrot juice differentadditives. Annals, Food Science and Technology 14(1): 34-38.

Marhamatizadeh, M.I., Rezazadeh, S., Kazemini, F. dan Kazemi, M.R. (2012). The study of probiotic juice product conditions supplemented by culture of $L$. acidophilus and Bifidobacterium bifidum. Middle East Journal of Scientific Research 11(3): 287-295.

Nosrati, R., Hashemiravan, M. dan Talebi, M. (2014). Fermentation of vegetables juiceby probiotic bacteria. International Journal of Bioscience 4(3): 171-180.

Nurwantoro, S., Hartanti, D. dan Sukoco (2009). Viabilitas Bifidobacterium bifidum, kadar laktosa dan rasa es krim simbiotik pada lama penyimpanan suhu beku yang berbeda. Jurnal Pengembangan Peternakan Tropis 34(1): 16-21.

Prado, F.C., Parada, J.L., Pandey, A. dan Soccol, C.R. (2008). Trends in non-dairy probiotic beverages. Food Research International 41(2): 111-123.

Retnowati, P.A. dan Kusnadi, J. (2014). Pembuatan minuman probiotik sari buah kurma (Phoenix dectylifera) dengan isolat Lactobacillus casei dan Lactobacillus plantarum. Jurnal Pangan dan Agroindustri 2(2): 1-6.

Saarela, M.H., Alakum, H.L., Puhakka, A.M. dan Matto, J. (2009). Effect of the fermentation $\mathrm{pH}$ on the storage stability of Lactobacillus rhamnosus and $L$. preparatums. Applied Microbiology 106: 1204-1212.

Santoso, P.J. (2010). Lai, durian berwarna atraktif potensi ekspor. Iptek Hortikultura 6: 1- 41.

Shin, H., Lee, J., Pestka, J.J. dan Ustunol, Z. (2000). Viability of Bifidobacteria in commercial dairy products during refrigerated storage. Journal of Food Protection 63: 327-331.

Soccol, C.R., Vandenberghe, L.P. de S., Spier, M.R., Medeiros, A.B.P., Yamaguishi, C.T., Lindner, J. de Dea., Pandey, A. dan Thomas-Soccol, V. (2010). The potential of probiotics: A Review. Food Technology Biotechnology 48(4): 413-434.

Standar Nasional Indonesia, SNI 202981. (2009). Syarat Mutu Minuman Susu Fermentasi Berperisa. Badan Standardisasi Nasional.

Usmiati, S. dan Utami, T. (2008). Pengaruh bakteri probiotik terhadap mutu sari kacang tanah fermentasi. Jurnal Pascapanen 5(2): 27-36.

Wahdah, R., Nisa, C. dan Langai, B.F. (2003). Karakterisasi sifat fisik buah dan kandungan gizi buah-buahan di lahan kering Kalimantan Selatan. Laporan Pengkajian BPTP Kalimantan Selatan Bekerja Sama dengan Fakultas Pertanian Universitas Lambung Mangkurat Banjarbaru. $122 \mathrm{hlm}$. 
Wang, C.Y., Ng, C.C., Su, H., Tzeng, W.S. dan Shyu, Y.T. (2009). Probiotic potential of noni juice fermented with lactic acid bacteria and bifidobacteria. InternationalJournalof Food Science and Nutrition 1: 1-9.

Widowati, S. dan Misgiyarta (2005). Efektifitas bakteri asam laktat (BAL) dalam pembuatan produk fermentasi berbasis protein/susu nabati. Prosiding Seminar Hasil Penelitian Rintisan dan Bioteknologi Tanaman. Balai Penelitian Bioteknologi dan Sumberdaya Genetik Pertanian.

Winarti, S., Harmayani, E., Marsono, Y. dan Pranoto, Y. (2013). Effect of inulin isolated from lesser yam (Dioscorea esculenta) on the growth of probiotics bacteria and SCFA formation during fermentation. International Research Journal of Microbiology 4(2): 53-63

Wright, A.V. dan Axelsson, L. (2011). Lactic acid bacteria: an introduction. Dalam: Lahtinen, S., Ouwehand, A.C., Salminen, S. dan Wright, A.V. (ed.). Lactic Acid Bacteria Microbiological and Functional Aspects, Fouth Edition: CRC Press, New York.

Yoon, K.Y., Woodams, E.E. dan Hang, Y.D. (2004). Probiotication of tomato juice by lactic acid bacteria. Journal of Microbiology 42: 315-318.
Yoon, K.Y., Woodams, E.E. dan Hang, Y.D. (2005). Fermentation of beet juice by beneficial lactic acid bacteria. Lebenmittel Wissenschaft und Technologie 38(1): 73-75.

Yoon, K.Y., Woodams, E.E. dan Hang, Y.D. (2006). Production of probiotic cabbage juice by lactic acid bacteria. Biores Technology 97(12): 1427-1430.

Yuliana, N. (2010). Kajian minuman laktat susu kelapa yang diberi sari ubijalar sebagai sumber prebiotik: viabilitas probiotik Lactobacillus casei selama penyimpanan dingin. Majalah TEGI, Teknologi Agroindustri 2(2): 20-29.

Yuliana, N., Nurdjanah, S. dan Margaretta, M. (2013).The effect of a mixed-starter culture of lactic acid bacteria on the characteristics of pickled orange-fleshed sweet potato (Ipomoea batatas). Microbiology Indonesia 7(1): 1-8.

Yuliana, N. (2013). Ilmu Pengolahan Durian Fermentasi (Tempoyak). Lembaga Penelitian Universitas Lampung. Bandar Lampung.

Zubaidah, E., Liasari, Y. dan Saparianti, E. (2008). Produksi eksopolisakarida oleh Lactobacillus plantarum B2 pada produk probiotik berbasis buah murbei. Jurnal Teknologi Pertanian 1(9): 59-68. 